\title{
Impact of Dissolved Oxygen Concentration and DPAOs: Nitrifiers Population Ratio on Nutrient Removal in EBPR Process
}

\author{
Masuduz Zaman, Xiaoguang Liu, and George Nakhla
}

\begin{abstract}
This study reports the effect of denitrifying phosphorus accumulating organisms (DPAOs) at low DO on simultaneous nitritation-denitritation and enhanced biological phosphorus removal process. DPAOs were enriched in a sequencing batch reactor (SBR) under anaerobic-anoxic-aerobic condition with an active DPAO population of about $30 \%$. The nitrite-oxidizing bacteria (NOB) washout from the nitrifying sludge was obtained in a separate SBR operated under anoxic-aerobic conditions. At a 1:1 ratio of nitrifying to DPAOs sludge neither nitrogen nor phosphorus removal was significantly affected at DO limited condition $(0.5$ $\mathrm{mg} / \mathrm{L}$ DO). However, as DPAOs to nitrifiers population ratio was further increased to 1:4, the effect of low DO was found to be more significant on nitrification than P-removal. This signifies the competitive advantages of DPAOs over nitrifiers under DO limited condition.
\end{abstract}

Index Terms-Denitrifying phosphorus accumulation organisms (DPAOs), nitrifiers, low DO nutrient removal, DPAO-nitrifiers competition.

\section{INTRODUCTION}

Enhanced biological phosphorus removal (EBPR) is a sustainable and environmentally friendly engineered wastewater treatment process that is capable of maintaining a low effluent phosphorus concentration. The fundamental principle of EBPR is the alternating anaerobic-aerobic or anoxic condition that promotes the growth PAOs, which can store VFAs under anaerobic conditions and utilize them under aerobic or anoxic conditions along with phosphorus uptake [1].

Aeration is the most energy intensive operation in wastewater treatment plant and accounts for $45 \%-75 \%$ of plant energy cost [2]. In recent years, optimizing aeration requirement has become an important task for municipal wastewater treatment plants. Recent technological developments are also more focused on low dissolved oxygen processes [3], [4]. In the conventional $\mathrm{A}^{2} \mathrm{O}$ process, high DO concentration in the aeration tank can led to greater oxygen contribution from nitrate recycle into the anoxic zone. This can favor the proliferation of denitrifying glycogen accumulating organisms (DGAOs) over denitrifying

Manuscript received April 1, 2019; revised July 2, 2019.

M. Zaman and G. Nakhla are with the Department of Chemical and Biochemical Engineering, Western University, 1151 Richmond Street, London, ON, N6A 3K7, Canada (e-mail: mzaman9@uwo.ca, gnakhla@uwo.ca).

$\mathrm{X}$. Liu is with the Department of Civil and Environmental Engineering, Western University, 1151 Richmond Street, London, ON, N6A 3K7, Canada (e-mail: xliu625@uwo.ca). phosphorus accumulating organisms (DPAOs) and deteriorate biological phosphorus removal [5]. While it is a common practice to maintain $2-3 \mathrm{mg} / \mathrm{L}$ of DO in the aeration tank for stable nitrogen and phosphorus removal, recent studies showed aerobic P-uptake is feasible at dissolved oxygen concentration below $1 \mathrm{mg} / \mathrm{L}$ [4].

This study investigates the impact of low dissolved oxygen concentration and DPAOs to nitrifiers population ratio on nutrient removal. The DPAOs enrichment process was carried out in a separate SBR, capable of utilizing both $\mathrm{NO}_{2}-\mathrm{N}$ and $\mathrm{O}_{2}$ as an electron acceptor. NOB washout from the nitrifying sludge was obtained in a separate SBR operated under low DO condition.

\section{EXPERIMENTALS}

\section{A. Sludge and Wastewater}

Synthetic wastewater was used for DPAOs enrichment with the following characteristics; $160 \mathrm{mg} / \mathrm{L}$ COD (acetate), 8 $\mathrm{mg} / \mathrm{L} \mathrm{NH} \mathrm{NH}_{4} \mathrm{~N}, 6 \mathrm{mg} / \mathrm{L} \mathrm{PO}_{4}-\mathrm{P}$, and trace metals $(70 \mathrm{mg} / \mathrm{L}$ $\mathrm{MgSO}_{4}, 0.06 \mathrm{mg} / \mathrm{L} \mathrm{CuSO}_{4} .5 \mathrm{H}_{2} \mathrm{O}, 0.24 \mathrm{mg} / \mathrm{L} \mathrm{MnCl}_{2} .4 \mathrm{H}_{2} \mathrm{O}$, $0.24 \mathrm{CoCl}_{2} \cdot 6 \mathrm{H}_{2} \mathrm{O}, 0.3 \mathrm{mg} / \mathrm{L} \mathrm{ZnCl}_{3}$. Partial nitrification SBR was operated with synthetic wastewater with following characteristics: $120 \mathrm{mg} / \mathrm{L}$ COD (acetate), $50 \mathrm{mg} / \mathrm{L} \mathrm{NH}_{4}-\mathrm{N}, 4$ $\mathrm{mg} / \mathrm{L} \mathrm{PO}_{4}-\mathrm{P}, 400 \mathrm{mg} / \mathrm{L}$ alkalinity (as $\mathrm{CaCO}_{3}$ ), and trace metals at the same concentration as DPAOs SBR. Activated sludge inoculum was obtained from Greenway wastewater treatment plant, London, ON, Canada. The wastewater and inoculum were stored at $4{ }^{\circ} \mathrm{C}$ prior to use.

\section{B. Analytical Methods}

All chemicals used were analytical grades and obtained from Sigma-Aldrich. TSS, VSS, and alkalinity were measured using methods APHA 2540D, 2540E, and 2320B, respectively. Water quality parameters were measured using the following $\mathrm{HACH}$ methods: COD (HACH 8000), total nitrogen (HACH10072), ammonia (HACH10031), nitrate (HACH 10020), nitrite (HACH 10019), reactive phosphorus (HACH 8114), and total phosphorus (HACH 10127).

\section{RESULTS AND DisCUSSIONS}

\section{A. DPOAs Enrichment in Mother SBR Reactor}

DPAOs enrichment in the mother SBR reactor was obtained according to the method outlined in the literature [6]. A SBR with $2 \mathrm{~L}$ effective working volume was operated with $50 \%$ filling ratio for 3 cycles per day. The operation sequence 
was as follows: $10 \mathrm{~min}$ fill, $90 \mathrm{~min}$ anaerobic, $180 \mathrm{~min}$ anoxic, $120 \mathrm{~min}$ aerobic, $70 \mathrm{~min}$ settling, and $10 \mathrm{~min}$ decant. The influent characteristics were as follows: $160 \mathrm{mg} / \mathrm{L}$ COD (acetate), $8 \mathrm{mg} / \mathrm{L} \mathrm{NH}_{4}-\mathrm{N}, 6 \mathrm{mg} / \mathrm{L} \mathrm{PO}_{4}-\mathrm{P}$, and trace metals. In order to prevent nitrification during the aerobic phase 20 $\mathrm{mg} / \mathrm{L}$ allylthiourea was also added in each phase. During the anoxic cycle, $\mathrm{NO}_{2}-\mathrm{N}$ was provided from a concentrated $\mathrm{NaNO}_{2}$ solution using a chemical feed pump. In each cycle, 3 spikes of $5 \mathrm{mg} / \mathrm{L} \quad \mathrm{NO}_{2}-\mathrm{N}$ were added for the anoxic phosphorus uptake. Fig. 1 shows a typical cycle of operation in the mother SBR

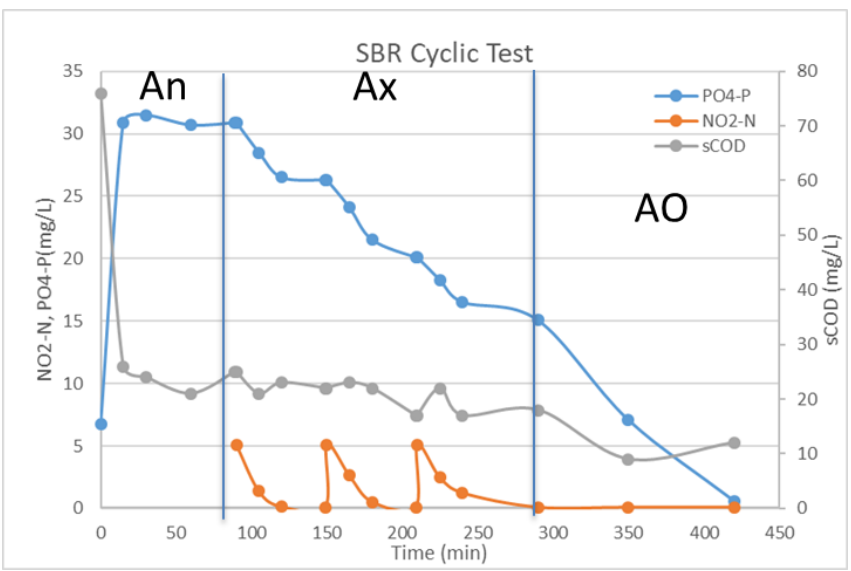

Fig. 1. Variations of N, P, COD in a typical cycle in the mother SBR.

As seen in Fig. 1, during the anaerobic phase most of the readily biodegradable carbon was utilized for synthesis of PHA. The sp. Phosphorus release rate was found to be 53 $\mathrm{mgPO}_{4}-\mathrm{P} / \mathrm{g}-\mathrm{VSS} . \mathrm{hr}$ (Table I) which is higher than the typically reported values of 5-32 $\mathrm{mgPO}_{4}-\mathrm{P} / \mathrm{g}-\mathrm{VSS} . \mathrm{hr}$ in the literature [7]-[10]. In the anoxic phases, all the added $\mathrm{NO}_{2}-\mathrm{N}$ was reduced along with phosphorus uptake. This confirms the enrichment of nitrite reductase enzyme in the DPAOs in the mother reactor. In both the anoxic and aerobic phases, specific P-uptake rate was found to be significantly lower compared to the reported values in literature. The typical values for aerobic P-uptake are reported to be between 5-20 $\mathrm{mgPO}_{4}-\mathrm{P} / \mathrm{g}-\mathrm{VSS} . \mathrm{hr}$ [7]-[10]. This is primarily due to the lack of $\mathrm{pH}$ control during the anoxic phase. The increased $\mathrm{pH} 8.2$ from anoxic cycle also significantly affected the aerobic $\mathrm{P}$-uptake rate as seen in Table 1 . The average $\mathrm{N}$ - reduced to P-uptake rate was found to be 1.05 which is lower than the typical reported values of 1.3-1.5 [6], [11] which signifies slightly lower carbon utilization efficiency in the enriched DPAOs culture.

TABLE I: KINETICS OF NUTRIENT REMOVAL IN MOTHER DPAO-SBR

\begin{tabular}{|c|c|c|c|c|c|}
\hline & An & Ax-1 & Ax-2 & Ax-3 & AO \\
\hline $\begin{array}{c}\text { SPRR } \\
\left(\mathbf{m g P O}_{\mathbf{4}} \text {-P/g-VSS.hr) }\right.\end{array}$ & 53 & & & & \\
\hline $\begin{array}{c}\text { SPUR } \\
(\mathbf{m g P O} \text {-P/g-VSS.hr) }\end{array}$ & & 4.9 & 5.3 & 4 & \\
\hline $\begin{array}{c}\text { SDNR } \\
(\mathbf{m g N O} \text {-N /g-VSS.hr) }\end{array}$ & & 5.5 & 5.1 & 4.3 & 3.7 \\
\hline $\begin{array}{c}\text { N-reduction } \\
\text { rate/P-uptake rate }\end{array}$ & & 1.12 & 0.96 & 1.07 & \\
\hline
\end{tabular}

\section{B. NOB Washout from Nitrifying Sludge}

A 2L SBR was inoculated with returned activated sludge from Greenway WWTP and operated 3 cycles/day. Low DO
(0.3-0.5 mg/L) coupled with short SRT (8 days aerobic SRT) facilitated the washout out of NOB and stable nitrite accumulation ratio, NAR (upto 85\%). Fig.2 shows the operational performance of the partial nitrification reactor. As shown in Fig. 2, no significant nitrite was accumulated in the effluent due to high NOB population in the first 2 weeks. At the start-up, the apparent sp. growth rates $\left(25^{\circ} \mathrm{C}\right.$, DO 0.25 $\mathrm{mg} / \mathrm{L}$, and aerobic SRT 8 days) for $\mathrm{AOB}$ and NOB was calculated to be, $0.103 \mathrm{~d}^{-1}$ and $-0.026 \mathrm{~d}^{-1}$, respectively. This is highly favorable for NOB washout and as seen in Fig. 2, after 2 weeks NOB washout started to take place and in about 2 months stable nitrite accumulation was achieved with NAR ranged from $80 \%$ to $85 \%$. Ammonium conversion ratio (ACR) was found to be more than $80 \%$ throughout the period of study. The biomass concentration stabilized at $240 \mathrm{mg}-\mathrm{MLVSS} / \mathrm{L}$ in about 40 days.

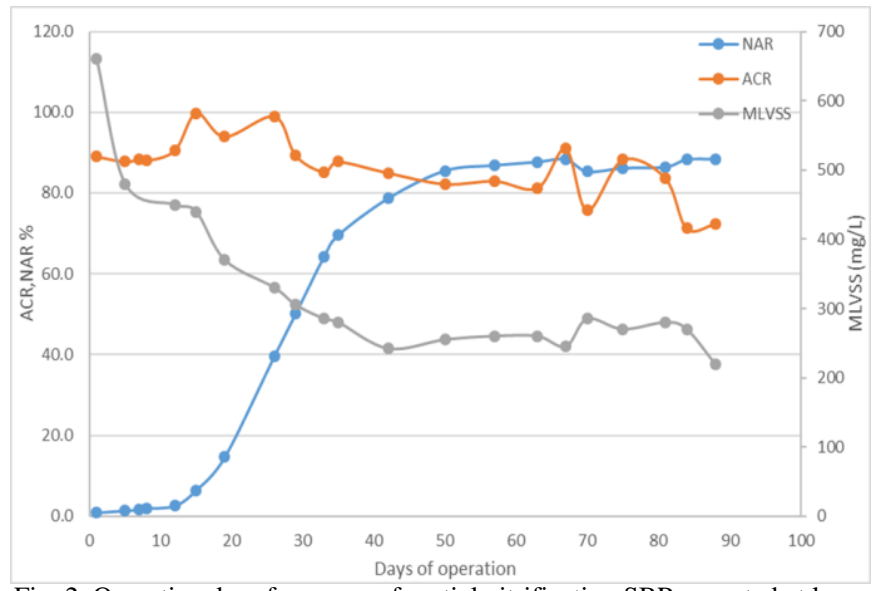

Fig. 2. Operational performance of partial nitrification SBR operated at low DO (0.3-0.5 mg/L) and short SRT (8 days).

\section{Batch Study on Nitrifiers and DPAOs Mixed Sludge at Various Nitrifying to DPAO Sludge Mass Ratios}

Batch studies were conducted with varying dissolved oxygen concentration and $\mathrm{N}$-sludge (nitrifying sludge) to P-sludge (DPAO sludge) ratios. Both nitrifying and DPAOs sludge was washed and centrifuged to make a concentrated stock. Concentrated N-sludge and P-sludge at specific ratios $(1: 1,1: 2,1: 4)$ was taken to a $250 \mathrm{~mL}$ conical flask and diluted to $250 \mathrm{~mL}$ with DI water. $\mathrm{N}, \mathrm{P}$, and COD was provided from concentrated stock solutions to provide an initial

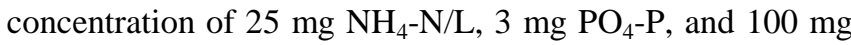
$\mathrm{sCOD} / \mathrm{L}$. Each batch study consists of 1 hour of anaerobic followed by 5 hour of aerobic contact time.

\section{Scenario 1. Varying $\mathrm{N}$-sludge to $P$-sludge ratio at $0.5 \mathrm{mg} / \mathrm{L}$ dissolved oxygen concentration}

Three batch tests were conducted to study the impact of DPAOs on nitrification at varying nitrifiers to DPAOs population ratio. The $\mathrm{N}$-sludge: $\mathrm{P}$-sludge ratio tested with incremental DPAOs population was as follows: 1:1, 1:2, 1:4 on mass basis. Tables II-IV show the initial, end of anaerobic phase and final effluent concentration in each of the batch tests.

As seen in Table II, DPAOs did not have any significant impact on nitrification at a N-Sludge: P-sludge ratio of $1: 1$. Most of the ammonium was oxidized and subsequently 
reduced by the ordinary denitrifiers as well as DPAOs. The ammonium conversion ratio (ACR) was about $99.5 \%$. The residual $\mathrm{NO}_{3}-\mathrm{N}$ concentration of $6.6 \mathrm{mg} / \mathrm{L}$ signifies DPAO's lack of capability to use nitrate as an electron acceptor. This is in agreement with the previous finding on DPAOs genome study which confirmed that DPAOs lacks the gene required for synthesis of nitrate reductase enzyme [12].

As the DPAOs population was increased in the sludge, ACR was reduced to $79 \%$ and $57 \%$ at a N-sludge: P-sludge ratio of $1: 2$ and 1:4, respectively (Tables III \& IV). This is a direct consequence of heterotopic microorganisms including DPAOs due to higher heterotopic oxygen uptake. As DPAOs can only partially utilized the $\mathrm{NO}_{2}-\mathrm{N}$ due to the presence of ordinary denitrifiers, thus continue to use oxygen as the electron acceptor, thereby, depriving the ammonium oxidizing bacteria from oxygen. As ammonium oxidation was negatively impacted, phosphorus removal was also negatively affected due to the lack of $\mathrm{NO}_{2}-\mathrm{N}$ availability and limited DO. However, the effect of low DO is less severe on DPAOs than nitrifiers, as evidenced by the much higher increase in final effluent ammonia concentration relative to phosphorus.

TABLE II: N, P, C TRANSFORMATION AT N-SLUDGE TO P-SLUDGE RATIO 1:1

\begin{tabular}{|c|c|c|c|}
\hline $\begin{array}{c}\text { Concentration } \\
(\mathbf{m g} / \mathbf{L})\end{array}$ & Initial & $\begin{array}{c}\text { Anaerobic } \\
\text { Effluent }\end{array}$ & $\begin{array}{c}\text { Final } \\
\text { Effluent }\end{array}$ \\
\hline $\mathrm{NH}_{4}-\mathrm{N}$ & 25 & 23.8 & 0.125 \\
\hline $\mathrm{PO}_{4}-\mathrm{P}$ & 3 & 11.1 & 3.54 \\
\hline $\mathrm{sCOD}$ & 100 & 55 & 10 \\
\hline $\mathrm{NO}_{3}-\mathrm{N}$ & 0 & 0 & 6.6 \\
\hline $\mathrm{NO}_{2}-\mathrm{N}$ & 0 & 0 & 0.03 \\
\hline
\end{tabular}

TABLE III: N, P, C TRANSFORMATION AT N-SLUDGE TO P-SLUDGE RATIO

\begin{tabular}{|c|c|c|c|}
\hline $\begin{array}{c}\text { Concentration } \\
(\mathbf{m g} / \mathbf{L})\end{array}$ & Initial & $\begin{array}{c}\text { Anaerobic } \\
\text { Effluent }\end{array}$ & $\begin{array}{c}\text { Final } \\
\text { Effluent }\end{array}$ \\
\hline $\mathrm{NH}_{4}-\mathrm{N}$ & 25 & 24.1 & 5.25 \\
\hline $\mathrm{PO}_{4}-\mathrm{P}$ & 3 & 17 & 4.33 \\
\hline $\mathrm{sCOD}$ & 100 & 40 & 14 \\
\hline $\mathrm{NO}_{3}-\mathrm{N}$ & 0 & 0 & 3 \\
\hline $\mathrm{NO}_{2}-\mathrm{N}$ & 0 & 0 & 0.15 \\
\hline
\end{tabular}

TABLE IV: N, P, C TRANSFORMATION AT N-SLUDGE TO P-SLUDGE RATIO $1: 4$

\begin{tabular}{|c|c|c|c|}
\hline $\begin{array}{c}\text { Concentration } \\
(\mathbf{m g} / \mathbf{L})\end{array}$ & Initial & $\begin{array}{c}\text { Anaerobic } \\
\text { Effluent }\end{array}$ & $\begin{array}{c}\text { Final } \\
\text { Effluent }\end{array}$ \\
\hline $\mathrm{NH}_{4}-\mathrm{N}$ & 25 & 23.5 & 10.7 \\
\hline $\mathrm{PO}_{4}-\mathrm{P}$ & 3 & 22 & 7.24 \\
\hline $\mathrm{sCOD}$ & 100 & 26 & 11 \\
\hline $\mathrm{NO}_{3}-\mathrm{N}$ & 0 & 0 & 1 \\
\hline $\mathrm{NO}_{2}-\mathrm{N}$ & 0 & 0 & 0.02 \\
\hline
\end{tabular}

Scenario 2. Varying dissolved oxygen concentration at $N$-sludge to $P$-sludge ratio of $1: 4$

In order to confirm the competition for oxygen between DPAOs and AOB, the oxygen concentration was further reduced to $0.2 \mathrm{mg} / \mathrm{L}$ at $\mathrm{N}$-sludge to P-sludge ratio of $1: 4$. Table $\mathrm{V}$ shows the initial, end of anaerobic phase and final effluent concentration.

As seen in Table V, under severe DO limited situation ACR was further reduced to $22 \%$. However, phosphorus continued to uptake by the DPAOs even in the absence $\mathrm{NO}_{2}-\mathrm{N}$. This result showed that denitrifying phosphorus accumulating organism can be detrimental for nitrifiers in DO limited condition in activated sludge process in the absence of abundant nitrite for P-uptake.

TABLE V: N, P, C TRANSFORMATION AT N-SLUDGE TO P-SLUDGE RATIO 1:4 AND DISSOLVED OXYGEN CONCENTRATION $0.2 \mathrm{MG} / \mathrm{L}$

\begin{tabular}{|c|c|c|c|}
\hline $\begin{array}{c}\text { Concentration } \\
(\mathbf{m g} / \mathbf{L})\end{array}$ & Initial & $\begin{array}{c}\text { Anaerobic } \\
\text { Effluent }\end{array}$ & $\begin{array}{c}\text { Final } \\
\text { Effluent }\end{array}$ \\
\hline $\mathrm{NH}_{4}-\mathrm{N}$ & 25 & 22.8 & 19.6 \\
\hline $\mathrm{PO}_{4}-\mathrm{P}$ & 3 & 23.5 & 9.59 \\
\hline $\mathrm{sCOD}$ & 100 & 21 & 14 \\
\hline $\mathrm{NO}_{3}-\mathrm{N}$ & 0 & 0 & 0.6 \\
\hline $\mathrm{NO}_{2}-\mathrm{N}$ & 0 & 0 & 0.07 \\
\hline
\end{tabular}

\section{CONCLUSION}

This study addressed the competition between denitrifying phosphorus accumulating microorganism and nitrifiers for dissolved oxygen in biological nutrient removal process. The enriched DPAOs culture, capable of using both nitrite and oxygen as electron acceptors, tends to dominate oxygen consumption under DO limited condition in the absence of nitrite. This can significantly impact the overall nutrient removal for EBPR processes operated at low DO concentration.

\section{CONFLICT OF INTEREST}

The authors declare no conflict of interest.

AUTHOR CONTRIBUTIONS

\begin{tabular}{|l|l|}
\hline Contributor & Statement of Contribution \\
\hline Masuduz Zaman & Conception \& Experimental \\
& design (60\%) \\
& Drafting paper (70\%) \\
& Conducting experiments (100\%) \\
& Data interpretation (50\%) \\
\hline Xiaoguang Liu & Conception \& Experimental \\
& design (20\%) \\
& Data interpretation (25\%) \\
\hline George Nakhla & Conception \& Experimental \\
& design (20\%) \\
& Drafting paper (30\%) \\
& Data interpretation $(25 \%)$ \\
\hline
\end{tabular}

The authors acknowledge the financial support from Natural Science and Engineering Research Council (NSERC) through Alexander Graham Bell Research Fellowship.

\section{REFERENCES}

[1] A. Oehmen et al., "Advances in enhanced biological phosphorus removal: From micro to macro scale," Water Res., vol. 41, no. 11, pp. 2271-2300, 2007.

[2] J. Gu et al., "Energy self-sufficient wastewater treatment plants: Feasibilities and challenges," Energy Procedia, vol. 105, pp. 3741-3751, 2017.

[3] H. Chen et al., "Effect of dissolved oxygen on biological phosphorus removal induced by aerobic / extended-idle regime," Biochem. Eng. J., vol. 90, pp. 27-35, 2014.

[4] J. A. Jimenez and P. Dold, "Mainstream nitrite-shunt with biological phosphorus removal at the city of St . Petersburg Southwest WRF," 2014.

[5] Q. Yuan and J. A. Oleszkiewicz, "Effect of dissolved oxygen on biological nutrient removal by denitrifying phosphorus-accumulating organisms in a continuous-flow system," pp. 1-8, 2011. 
[6] H. Dai, X. Lu, L. Peng, X. Li, and Z. Dai, "Enrichment culture of denitrifying phosphorus removal sludge and its microbial community analysis," vol. 3330, no. September, 2017.

[7] D. Mamais and D. Jenkins, "The effect of MCRT and temperature on enhanced biological phosphorus removal," Water Sci. Technol., vol. 26, pp. 955-965, 1992.

[8] T. Kuba, M. C. M. Van Loosdrecht, F. A. Brandse, and J. J. Heijnen, "Occurrence of denitrifying phosphorus removing bacteria in modified UCT-type wastewater treatment plants," Water Environ. Res., vol. 31, no. 4, pp. 777-786, 1997.

[9] M. C. M. Brdjanovic et al.,"Effect of polyphospbate limitation on the anaerobic metabolism of phosphorus-accumulating microorganisms," Appl. Microbiol. Biotechnol., vol. 50, no. 2, pp. 273-276, 1998.

[10] A. Monti, E. Hall, and M. C. M. Loosdrecht, "Kinetics of phosphorus release and uptake in a membrane-assisted biological phosphorus removal process," J. Environ. Eng., vol. 133, no. September, pp. 899-908, 2007.

[11] Y. Z. Peng, C. Y. Wu, R. D. Wang, and X. L. Li, "Denitrifying phosphorus removal with nitrite by a real-time step feed sequencing batch reactor," J. Chem. Technol. Biotechnol., vol. 86, no. 4, pp. 541-546, 2011.

[12] A. C. Mchardy et al., "Metagenomic analysis of two enhanced biological phosphorus removal ( EBPR ) sludge communities," vol. 24 , no. 10, pp. 1263-1269, 2006.

Copyright $\odot 2019$ by the authors. This is an open access article distributed under the Creative Commons Attribution License which permits unrestricted use, distribution, and reproduction in any medium, provided the original work is properly cited (CC BY 4.0).

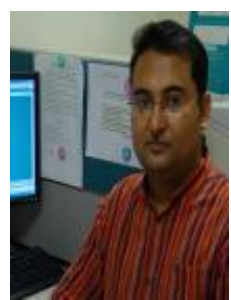

Masuduz Zaman obtained his BSc in chemical engineering from Bangladesh University of Engineering and Technology, Bangladesh in 2007 and the MPhil in chemical engineering from University of Queensland, Australia in 2015. He has published more than 10 research articles in prestigious journals and conferences including Water Research, Carbohydrate Polymers, AIChE, etc. His research has received 360+ citations with $\mathrm{H}$ and $\mathrm{I}$ index of 6 and 5, respectively (google scholar). He is currently pursuing his $\mathrm{PhD}$ degree in environmental engineering at Western University with a focus on biological nutrient removal. He is a recipient of Alexander Graham Bell $\mathrm{PhD}$ Fellowship from Natural Science and Engineering Council of Canada for conducting his doctoral research.

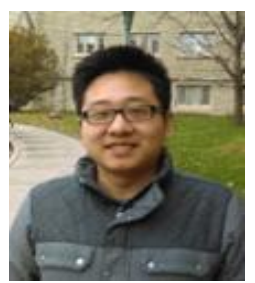

Xiaoguang Liu obtained his BSc, in 2011 and MSc, in 2014 from Tongji University majoring in environmental engineering. He received his $\mathrm{PhD}$ in civil and environmental engineering from the Western University, Canada in 2018. His thesis was on experimental testing and modeling of partial nitrification at different temperatures. He is currently a postdoctoral fellow in the Department of Civil \& Environmental Engineering at Georgia Institute of Technology, Atlanta, USA.

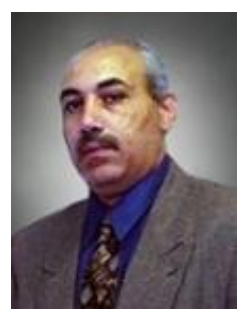

George Nakhla obtained his BSc from University of Khartoum, Sudan in 1983 and the MSc, PhD from University of Illinois-Urbana Champaign in 1987 and 1989 , respectively. He is currently professor of civil and environmental engineering at the Western University, Canada. His research interests lie in the area of municipal and industrial wastewater treatment, biological nutrient removal, anaerobic digestion, biological detoxification of hazardous contaminants, soil and ground water bioremediation, and landfill leachate treatment. 